\title{
DEMOKRASI KOTAK KOSONG (Studi Kasus Pada Pemilukada Kota Jayapura Tahun 2017)
}

\author{
Oleh: \\ Senalince Mara \\ Prodi PPKn FKIP Universitas Cendrawasih \\ ogespapua@gmail.com
}

\begin{abstract}
ABSTRAK
Kehidupan berdemokrasi di Tanah Air terus mengalami perkembangan yang dinamis. Perbaikan demi perbaikan dilakukan dengan memetik pengalaman di masa lalu. Pun demikian dalam pelaksanaan pemilihan kepala daerah. Kemandekan hukum yang disebabkan tidak diperbolehkannya calon tunggal dalam pilkada dipecahkan Mahkamah Konstitusi. Pilkada tetap bisa berlanjut meski hanya ada satu pasangan calon yang maju. Hal itu kemudian diatur dalam Undang-Undang No 10 Tahun 2016 tentang Pilkada. Seyogianya proses pencalonan yang berujung pada calon tunggal merupakan kondisi kedaruratan. Hal demikian pun terjadi pada pemilihan Walikota Jayapura periode 2017-2022, pada saat pendaftaran calon wali kota-dan wakil wali kota di ikuti oleh tiga pasangan calon, dan ketika verifikasi berkas satu calon dinyatakan gagal alias tidak lulus administrasi oleh KPUD Kota Jayapura, dan hanya tersisa dua calon, namun dalam waktu berjalan satu calon lagi dinyatakan gagal oleh keputusan Mahkama Agung, dengan demikian maka pemilihan wali kota dan wakil wali kota tahun 2017 hanya di ikuti oleh satu pasangan calon. Adapun tujuan dalam adalah untuk mengetahui parisipasi masayrakat pada pemilihan Wali kota Jayapura Tahun 2017 Hasil penelitian menenjukan KPU Kota Jayapura secara resmi menetapkan Paslon Tunggal dalam Pemilihan Walikota dan Wakil Walikota Jayapura, tahun 2017, yang memenuhi syarat pasangan calon atas nama DR. Benhur Tomy Mano, MM dan Ir. H. Rustan Saru, MM (BTM-Harus). Menurut Mukri, Keputusan KPU Kota Jayapura Nomor 4 Kpts/Kpu-Kt-Jpr/I/ 2017 tentang penetapan Paslon Tunggal dalam pemilihan Walikota dan Wakil Walikota Jayapura tahun 2017 pada tanggal 11 Januari 2017 yang ditandatangani Ketua KPU Kota Jayapura Yermis Numberi. Akibatnya partisipasi pemilih di Kota Jayapura, dalam pemilihan wali kota dan wakil wali kota mengalami penurunan 30 hingga 40 persen karena kurang adanya sosialisis kepada masayrakat.
\end{abstract}

Kata Kunci:Demokrasi, Kotak Kosong, Pilkada 


\section{PENDAHULUAN}

Sejak manusia mengenal demokrasi dan melaksanakan pemilihan sebuah kepala daerah, penyelenggara negara atau pemerintahan yang berdasarkan pada prinsip demokrasi yaitu "dari rakyat, oleh rakyat dan untuk rakyat", menjadi impian selurah bangsa. Momentum itu memperoleh peluang besar ketika tahun 2014, Indonesia masuk era reformasi, dimana masayarakat berhak memilih langsung wakil rakyatnya, momentum 2014 dianggap saat yang tepat untuk mengawali upaya meluruskan jalannya reformasih.pilihlah calon atau partai yang menjanjikan harapan itu sehingga demokrasi dapat berjalan dengan baik.

Kemunculan UU Nomor 32 Tahun 2004 sebagai pengganti UU Nomor 22 Tahun 1999 tentang Pemerintahan Daerah yang sekaligus menandakan lahirnya Pemilukada langsung di berbagai daerah di Indonesia diharapkan mampu membawa perubahan bagi bangsa ini di dalam merencanakan agenda reformasi yang lebih demokratis (Irtanto, 2008:01), kehadiran Undang-Undang tersebut merupakan peluang untuk mewujudkan aspirasi daerah yaitu keinginan untuk memiliki pemimpin lokal yang disepakati oleh rakyat melalui Pemilukada langsung. Kumorotomo (2005:108) mengemukakan mekanisme pemilihan seperti yang tertuang dalam UU Nomor 22 Tahun 1999 dinilai belum mampu menciptakan pemimpin daerah yang lebih akuntabel terhadap masyarakat setempat. Pilkada langsung yang kemudian mulai dilaksanakan pada 1 Juni 2005 (Amirudin dan Bisri, 2006:16) merupakan sebuah implementasi kebijakan pemerintah pusat serta merupakan proses demokrasi masyarakat di tingkat lokal. Hal baru ini tentunya tidak ditemukan oleh masyarakat pada masa Orde Baru sebelumnya. Jadi sekarang ini, Kepala Daerah tidak lagi ditentukan dan diangkat oleh pemerintah pusat bahkan dipilih oleh anggota DPRD di setiap daerah, melainkan dipilih langsung oleh masyarakat setempat, sehingga proses demokrasi yang berjalan di negara ini dapat dilakukan secara menyeluruh. Kendati demikian, perubahan sistem politik dengan diberlakukannya sistem pemilihan langsung di daerah tidak sepenuhnya memberikan arti perubahan yang positif. Pemilukada langsung pada praktiknya ternyata memunculkan serangkaian konflik dalam pelaksanaanya. Hal tersebut berbanding terbalik (Amirudin dan Bisri, 2006:12) dengan tujuan awal diterapkannya sistem pemilihan langsung untuk menciptakan pemimpin daerah yang lebih berkualitas.

Berbagai kecenderungan proses dan hasil Pemilukada tetap merupakan bahan kajian yang menarik. Kecenderungan proses pencalonan dan koalisi antarpartai dalam mengajukan kandidat atau pasangan calon adalah salah satu fenomena paling menarik di balik penyelenggaraan Pemilukada di Indonesia. Daya tarik itu tidak hanya terletak pada kecenderungan yang berbeda dengan yang terjadi di tingkat nasional melainkan partai-partai yang secara ideologis sering dipandang sangat berbeda satu sama lain bahkan bisa saling berkoalisi dalam mangajukan pasangan kandidat dalam Pemilukada yang cenderung berbeda dengan hasil pemilu legislatif.

Sistem kehidupan berdemokrasi di Tanah Air terus mengalami perkembangan yang dinamis. Perbaikan demi perbaikan dilakukan dengan memetik pengalaman di masa lalu. Pun demikian dalam pelaksanaan pemilihan kepala daerah. Kemandekan hukum yang disebabkan tidak diperbolehkannya calon tunggal dalam pilkada dipecahkan Mahkamah Konstitusi. Pilkada tetap bisa berlanjut meski hanya ada satu pasangan calon yang maju. Hal itu kemudian diatur dalam Undang-Undang No 10 Tahun 2016 tentang Pilkada. Seyogianya proses pencalonan yang berujung pada calon tunggal merupakan kondisi kedaruratan. Sebuah kondisi ketika sudah benar-benar tidak ada calon lain yang layak. Namun, ternyata situasi yang 
sebetulnya darurat itu cenderung semakin banyak terjadi. Pada pilkada serentak 2015 tercatat tiga daerah yang memiliki calon tunggal, dari 269 daerah yang menyelenggarakan pilkada. Di pilkada berikutnya yang terselenggara tahun ini, jumlah daerah dengan calon tunggal meningkat menjadi enam daerah. Bahkan, calon tunggal nyaris terjadi di tujuh daerah bila tidak muncul yang tampil merupakan sosok pemimpin yang berintegritas dengan kinerja yang unggul, tentu tidak terlau merisaukan. Akan tetapi, terbuka pula kemungkinan bahwa calon itu merupakan hasil kongkalikong disertai politik uang. Tujuannya jelas, demi mengamankan kekuasaan.

Hal demikian pun terjadi pada pemilihan Walikota Jayapura periode 2017-2022, pada saat pendaftaran calon wali kota-dan wakil wali kota di ikuti oleh tiga pasangan calon, dan ketika verifikasi berkas satu calon dinyatakan gagal alias tidak lulus administrasi oleh KPUD Kota Jayapura, dan hanya tersisa dua calon, namun dalam waktu berjalan satu calon lagi dinyatakan gagal oleh keputusan Mahkama Agung, dengan demikian maka pemilihan wali kota dan wakil wali kota tahun 2017 hanya di ikuti oleh satu pasangan calon.

Patutkah kita berharap kepala daerah yang didapatkan dari hasil kolusi tersebut bakal mengelola pemerintahan dengan bersih? Yang sangat mungkin terjadi ialah pemerintahan akan berjalan seperti di beberapa kabupaten di Indonesia yakni Setiap jabatan diberi label harga. Tiap proyek ada tarifnya. Hasilnya masuk kantong pribadi atau kelompok. Namun Publik cukup bisa bernapas lega saat Undang-Undang Pilkada mengatur pilihan lain bagi warga selaku penentu akhir pemilihan kepala daerah. Calon tunggal harus mendapatkan lebih dari 50\% suara untuk bisa terpilih. Pemegang hak suara boleh mencoblos kolom atau kotak kosong jika tidak ingin calon tunggal itu meraih kemenangan.Meski ada saluran 'kotak kosong, masyarakat sesungguhnya berada di posisi yang merugi. Ketika calon tunggal menang, pemimpin yang didapat belum tentu yang terbaik karena ketiadaan kompetisi. Sebaliknya, saat 'kotak kosong' menang, untuk sementara daerah dipimpin pejabat yang memiliki kewenangan terbatas. Pilkada ulang harus diselenggarakan hingga terpilih kepala daerah definitif. Lingkaran setan bisa tercipta karena calon tunggal yang kalah tetap boleh maju kembali menjadi calon. Satu calon pada pemilihan wali kota jayapura menjadi sesuatu yang sangat baru bagi masyarakat kota Jayapura.

\section{TINJAUAN TEORITIS Pilkada}

Pemilu diselenggarakan dengan tujuan untuk memilih wakil rakyat dan wakil daerah, serta untuk membentuk pemerintahan yang demokratis, kuat, dan memperoleh dukungan rakyat dalam rangka mewujudkan tujuan nasional sebagaimana Undang-Undang Dasar Negara Republik Indonesia Tahun 1945.

Pemilihan umum (Pemilu) menurut Haris (1998:10) merupakan salah satu bentuk pendidikan politik bagi rakyat, yang bersifat langsung, terbuka, massal, yang diharapkan bisa mencerdaskan pemahaman politik dan meningkatkan kesadaran masyarakat mengenai demokrasi. Dalam pasal 1 ayat (1) UU No. 22 Tahun 2007 tentang Penyelenggaraan Pemilihan Umum disebutkan dan dijelaskan tentang pengertian Pemilihan Umum.

Sejalan dengan pandangan di atas Hutington (dalam Rizkiyansyah, 2007:3) menyatakan bahwa "sebuah negara bisa disebut demokratis jika didalamnya terdapat mekanisme pemilihan umum yang dilaksanakan secara berkala atau periodik untuk melakukan sirkulasi elite". Sedangkan, Rizkiyansyah (2007:3) "Pemilihan Umum adalah salah satu pranata yang paling representatif atas berjalannya demokrasi, tidak pernah ada demokrasi tanpa pemilihan umum". 
Penjelasan di atas menunjukan bahwa pemilihan umum sebagai sarana terwujudnya demokrasi. Pemilihan umum adalah suatu alat yang penggunaannya tidak boleh mengakibatkan rusaknya sendisendi demokrasi dan bahkan menimbulkan hal-hal yang menderitakan rakyat, tetapi harus tetap tegaknya Pancasila dan dipertahankannya Undang-Undang Dasar 1945.

\section{Teori-Teori Pemilihan Umum}

Permana (dalam Pradhanawati (Peny), 2005:85) kata kunci dari pemilu langsung oleh rakyat adalah "kedaulatan rakyat". Dengan demikian, reputasi demokrasi tidak diragukan lagi adalah pemaknaan yang sesungguhnya dari kedaulatan rakyat itu sendiri. Schumpeter (dalam Sorensen, 2003:14) merumuskan pengertian demokrasi secara sederhana merupakan sebuah metode politik, sebuah mekanisme untuk memilih pemimpin politik. Warga negara diberikan kesempatan untuk memilih salah satu di antara pemimpin-pemimpin politik yang bersaing meraih suara. Pengertian demokrasi menunjukan bahwa keikutsertaan rakyat merupakan kunci utama dalam menjalankan sistem pemerintahan yang demokrasi. Keikutsertaan rakyat dalam sistem pemerintahan bisa dilakukan secara langsung oleh rakyat itu sendiri maupun melalui perwakilan hal tersebut dapat terwujud dengan dilaksanakannya Pemilihan Umum di Negara Indonesia.

Henry B. Mayo (dalam Budiarjo, 2008:117) memberikan definisi demokrasi sebagai berikut: Sistem politik yang demokratis ialah dimana kebijaksanaan umum ditentukan atas dasar mayoritas oleh wakil-wakil yang diawasi secara efektif oleh rakyat dalam pemilihan-pemilihan berkala yang didasarkan atas prinsip kesamaan politik dan diselenggarakan dalam suasana terjaminnya kebebasan politik. (A democratic political system is one in which public policies are made on a majority basis, by representatives subject to effective popular control at periodic elections which are conducted on the principle of political equality and under conditions of political freedom).

Pendapat Mayo tersebut oleh Budiarjo (2000:118) disimpulkan "bahwa demokrasi tidak hanya merupakan suatu sistem pemerintahan, tetapi juga suatu gaya hidup serta tata masyarakat tertentu, karena itu juga mengandung unsur-unsur moril.

Lary Diamond, Juan J Linz dan Seymour Martin Lipset (dalam Sorensen, 2003:19) memaknai demokrasi sebagai sebuah sistem pemerintahan yang memenuhi tiga kondisi-kondisi berikut: a). Kompetisi yang luas dan bermakna di antara individu dan kelompok organisasi (khususnya partai-partai politik) pada seluruh posisi kekuasaan pemerintah yang efektif, dalam jangka waktu yang teratur dan meniadakan penggunaan kekerasan; b). Tingkat partisipasi politik yang inklusif dalam pemilihan pemimpin dan kebijakan, paling tidak melalui pemilihan bebas secara teratur, dan tidak ada kelompok sosial (dewasa) utama yang disingkirkan; c). Tingkat kebebasan politik dan sipil, yaitu kebebasan berpendapat, kebebasan pers, kebebasan untuk mendirikan dan menjadi anggota organisasi, yang cukup untuk memastikan integritas partisipasi dan kompetisi politik.

Dari nilai-nilai beserta kondisikondisi demokrasi di atas maka dalam pemilihan umum juga terdapat nilai-nilai dan kondisi-kondisi tersebut. Pemilihan umum dapat dikatakan sebagai suatu "pesta demokrasi" di negara Indonesia. Mencermati praktik Pemilu dalam sistem politik modern, Eef Saefullah Fatah (dalam Rizkiyansyah, 2007:4) menyatakan bahwa: Pemilu dapat dibedakan menjadi dua tipe. Pertama, Pemilu sebagai formalitas politik, yakni, Pemilu hanya dijadikan alat legalisasi pemerintahan nondemokratis. Pemilunya sendiri dijalankan secara tidak demokratis; Kedua, yakni Pemilu sebagai alat demokrasi, 
Pemilu dijalankan secara jujur, bebas, bersih, kompetitif, dan adil. Pemerintah yang menyelenggarakan Pemilu bahkan kerap kali menerima kenyataan bahwa Pemilu yang mereka adakan justru menyingkirkan mereka dari tampuk kekuasaan.

Pemilu kepala daerah yang dilaksanakan di Indonesia saat ini merupakan pemilu yang ditempatkan pada tipe kedua yaitu pemilu sebagai alat demokrasi untuk menciptakan suatu pemerintahan yang refresentatif yang dijalankan secara jujur, bebas, bersih, kompetitif

\section{Tinjauan Tentang Pemilihan Umum Kepala Daerah \\ Pengertian Pemilihan Umum Kepala Daerah}

Proses demokratisasi kehidupan politik di Indonesia telah memasuki tahapan lanjut yakni pemilihan umum kepala daerah secara langsung (selanjutnya disingkat Pemilukada). Menyusul suksesnya pemilihan presiden secara langsung, semakin kuat pula keinginan rakyat untuk menentukan sendiri para pemimpin di daerah mereka. Menurut Samawi (dalam Afifi, Loy, DN (Ed), 2005:59) pemilihan kepala daerah secara langsung merupakan hasil penting dari proses reformasi.

Hasil ini harus dimanfaatkan masyarakat agar dapat ambil bagian aktif dalam proses pembentukkan pemerintah daerah dengan memilih langsung calon kepala daerah yang di pandang mampu dan berintegrasi pemilihan umum Kepala Daerah dan Wakil Kepala Daerah adalah Pemilu rakyat langsung tertangani oleh kepala daerah yang terpilih, karena pengalaman untuk memilih kepala daerah dan wakil kepala daerah secara langsung dalam Negara kesatuan Republik Indonesia berdasarkan Pancasila dan Undang-Undang Dasar 1945 bahwa:

a. Memiliki hubungan yang langsung dan dekat dengan rakyat. b. Mengerti dan memahami betul masalahmasalah rakyat dan memiliki antusiasme yang tinggi untuk menyelesaikan persoalan rakyat sesuai dengan kemampuannya. Melalui pemilihan umum kepala daerah diharapkan aspirasi dan kesejahteraa. (Pasal 1 (4) UU No 22 Tahun 2007). Pengertian kepala daerah dan wakil kepala daerah adalah Gubernur dan Wakil Gubernur untuk Provinsi, Bupati dan Wakil Bupati untuk Kabupaten, serta Walikota dan Wakil Kota untuk Kota. Amirudin dan Bisri (2006:25) menyatakan bahwa: "Ciri utama dari Pemilukada adalah terletak pada pergeseran pola pemilihan, dari elite vote menjadi model popular vote yang berarti menggeser medan permainan politik dari yang semula ada di ruang tertutup ke ruang terbuka, yang dulu dipilih di ruang DPRD menjadi dipilih di ruang publik." Pemilukada yang sukses harus ditandai dengan terpilihnya kepala daerah yang benar-benar sesuai dengan hati nurani rakyat yaitu kepala daerah yang terpilih secara adil, sehat, dan demokratis.

\section{Demokrasi}

Demokrasi adalah bentuk pemerintahan yang setiap warga negara memiliki hak yang setara dalam pengambilan keputusan yang menentukan hidup mereka. Demokrasi juga dapat diartikan sebagai bentuk pemerintahan yang dipegang oleh rakyat atau rakatlah yang mempunya kedaulatan tertinggi. Demokrasi mengisinkan warga negaranya untuk berpartisipasi baik secara langsung atau dengan perwakilan dalam perumusan, pengembangan, dan juga pembuatan hukum.

Demokrasi berasal dari bahasa Yunani dari kata Demokratia yang berarti "kekuasaan rakyat". Demokratia terdiri dari dua kata yaitu demos yang berarti rakyat dan kratos yang berarti kekuatan atau kekuasaan. Demokrasi mencakup kondisi sosial, ekonomi dan budaya yang memungkin dalam terjadinya praktik 
kebebasan politik baik secara bebas dan setara.

\section{Macam-Macam Demokrasi}

Demokrasi banyak dipakai suatu negara dengan banyak macam-macamnya. Jadi, mengenai macam-macam demokrasi dapat dikelompokkan dalam beberapa pembagian antara lain sebagai berikut..

a. Macam-Macam Demokrasi Berdasarkan Penyaluran Kehendak Rakyat

Demokrasi Langsung (Direct

Democracy): Pengertian demokrasi langsung adalah demokrasi yang secara langsung dalam melibatkan rakyat untuk pengambilan keputusan terhadap suatu negara. Demokrasi langsung, rakyat secara langsung berpartisipasi dalam pemilihan umum dan menyampaikan kehendaknya.

b. Demokrasi Tidak Langsung (Indirect

Democracy): Pengertian demokrasi tidak langsung adalah demokrasi yang tidak secara langsung melibatkan seluruh rakyat suatu negara dalam pengambilan keputusan. Demokrasi tidak langsung, rakyat menggunakan wakil-wakil yang telah dipercaya untuk menyampaikan aspirasi dan kehendaknya. Sehingga dalam demokrasi tidak langsung wakil rakyat terlibat secara langsung dengan menajd perantara seluruh rakyat.

\section{Kotak Kosong}

Menurut Ketua Komisi Pemilihan Umum (KPU) Provinsi Bali, Dewa Wiarsa Raka Sandi dalam (TRIBUN-BALI.COM, DENPASAR ) bahwa kotak kosong yang dimaksudnkan ini bukan kotak suara yang tak ada pemilihnya tetapi yang dilawan nanti adalah kotak kosong tanpa paslon. begitupun"Di Tasikmalaya sudah pernah ada satu paslon tetapi ada foto paslon tersebut dibawahnya setuju atau tidak setuju. Kalau sekarang buka surat suara ada foto pasangan calon ada juga nanti foto kosong (tanpa paslon) di sebelahnya (kalau nanti diputuskan satu paslon)," jelasnya. Ia pun menjelaskan bahwa masyarakat Buleleng tetap bisa memilih ke Tempat Pemungutan Suara (TPS).
Jadi bukan berarti kotak kosong tersebut tidak bisa dipilih."Prinsip yang kami tekankan, hak konstitusi warga negara. Memang KPU memutuskan masyarakat masih bisa ke TPS untuk mencoblos," jelasnya.

Dipaparkannya juga bahwa pemenang dari Pilkada Buleleng 2017 nantinya hanya akan ada satu paslon. Hal itu terjadi ketika calon tersebut mampu memperoleh suara $50 \%$ plus satu. "Kalau benar-benar satu paslon, pasangan calon menang kalau memperoleh $50 \%$ plus 1 . Kalau kotak kosong menang maka Pilkada Buleleng ikut pilkada serentak 2018. PASS pun masih bisa mengikuti Pilkada 2018 jikalau kalah oleh kotak kosong di 2017. Karena di aturan tidak ada menyebutkan tidak boleh ikut Pilkada lagi kalau kalah, kecuali sudah menjabat 2 periode," jelasnya.

Wacana penerapan bumbung kosong atau kotak kosong dalam pemilihan kepala daerah (Pilkada) serentak Desember 2015 dinilai tidak rasional. Sebab, pasangan calon kepala daerah dan wakil kepala daerah yang menang melawan bumbung kosong tidak akan mempunyai kebanggaan, jika kalah justru memalukan. Demikian dikemukakan pakar politik Ryaas Rasyid di Jakarta, Sabtu (1/8). "Masak lawan kotak kosong. Menang enggak bangga, kalah malu. Bumbung kosong tidak rasional," katanya.

\section{METODOLOGI PENELITIAN}

Berdasarkan pada rumusan masalah dan tujuan yang hendak dicapai, maka bentuk penelitian ini adalah kualitatif dengan strategi pendekatan deskriptif yang dianggap relevan dengan pokok penelitian ini. Penelitian kualitatif adalah prosedur penelitian yang menghasilkan data deskriptif berupa kata-kata tertulis atau lisan dari orang-orang dan pelaku yang dapat diamati Taylor dan Maleong dalam (Maman Rahman, 1993:145).

Alasan peneliti memilih pendekatan ini, karena masalah yang diteliti tahun 2017 
adalah tahun dimana terjadi pemilihan Walo Kota Jayapura, Dari penelitian ini diharapkan dapat dikumpulkan data sebanyak mungkin dari informasiinformasih dan data-data yang akurat. Alasan lainnya mengapa peneliti memilih penelitian kualitatif dengan pendekatan deskritif karena data yang akan diperoleh dari penelitian ini di lapangan lebih banyak menyangkut perbuatan dang ungkapan katakata dari responden yang sedapat mungkin bersifat alami, tanpa adanya rekayasa serta pengaruh dari luar. Sebagaimana Moleong (2003:3) mengatakan bahwa "penelitian kualitatif merupakan prosedur penelitian yang menghasilkan data kualitatif berupa kata-kata tertulis maupun lisan dari perilaku orang-orang yang diamati”.

Penelitian ini juga menggunakan studi kasus atau penelitian kasus (case study), adalah penelitian tentang status penelitian yang berkenan dengan suatu fase spesifik atau kas dari keseluruhan personalitas (Maxfield, 1930). Selanjutnya Nazir (2007:65), menjelaskan bahwa studi kasus atau case study adalah: Penelitian yang subyek penelitiannya dapat berupa individu, kelompok, lembaga maupun masyarakat. sehingga dapat memberikan gambaran secara mendetail tentang latar belakang, sifat-sifat serta karakter-karakter yang khas diats akan dijadikan suatu hal yang bersifat umum.

Berdasarkan metode di atas, maka penulisan dalam penelitian ini menggunakan teknik-teknik pengumpulan data sebagai berikut: Observasi /Pengamatan, Wawancara, Studi Dokumentasi

\section{PEMBAHASAN HASIL PENELITIAN} Faktor-Faktor Penyebab Terjadinya Satu Pasangan Calon Pada Pemilihan Walikota Jayapura Tahun 2017

KPU Kota Jayapura dan Pemkot Jayapura sebagai pembina politik di Kota Jayapura terkait Pilkada Kota Jayapura periode 2017-2022, untuk pertama kalinya menyelenggarakan Pilkada dengan
Pasangan Calon (Paslon) Tunggal, dan demi kelancaran pesta demokrasi ini didesak segera melakukan sosialisasi mekanisme Paslon tunggal, tata cara pencoblosan dan desain surat suara dan lain-lain yang terkait pelaksanaan Pilkada Serentak Kota Jayapura tanggal 15 Pebruari 2017 lalu, baik kepada penyelenggara di tingkat PPD (Distrik), TPS (Kelurahan/Kampung dan KPPS (RT/RW).

KPU Kota Jayapura secara resmi menetapkan Paslon Tunggal dalam Pemilihan Walikota dan Wakil Walikota Jayapura, tahun 2017, yang memenuhi syarat pasangan calon atas nama DR. Benhur Tomy Mano, MM dan Ir. H. Rustan Saru, MM (BTM-Harus). Menurut Mukri, Keputusan KPU Kota Jayapura Nomor 4 Kpts/Kpu-Kt-Jpr/I/ 2017 tentang penetapan Paslon Tunggal dalam pemilihan Walikota dan Wakil Walikota Jayapura tahun 2017 pada tanggal 11 Januari 2017 yang ditandatangani Ketua KPU Kota Jayapura Yermis Numberi.

Kesatu, menetapkan Paslon Tunggal dalam Pemilihan Walikota dan Wakil Walikota Jayapura, tahun 2017, yang memenuhi syarat pasangan calon atas nama BTMHarus.

Kedua, mengumumkan secara resmi hasil penetapan Paslon Tunggal sebagaimana dimaksud dalam Diktum kesatu.

Ketiga, Keputusan ini berlaku sejak tanggal ditetapkan 11 Januari.

Sebelumnya, KPU Kota Jayapura memutuskan dan menetapkan. Kesatu, membatalkan Surat KPU Kota Jayapura Nomor 56 Kpts/Kpu/Kt-Jpr/X 2016 tentang penetapan pasangan calon dalam pemilihan Walikota dan Wakil Walikota Jayapura 2017 tangal 24 Oktober 2016 atas nama DR. Benhur Tommy Mano, MM - Ir. H. Rustan Saru, MM dan Boy Markus Dawir, SP dan DR. H. Nuralam, MSi, SE. Kedua, Keputusan ini mulai berlaku sejak tanggal ditetapkan 11 Januari 2017. Berdasarkan hal itu, ungkapnya, pihaknya telah menerima SK tersebut dari Ketua KPU 
Kota Jayapura Yermis Numberi, karena telah menjalankan Putusan Mahkamah Agung $\quad$ RI Nomor 575 K/TUN/PILKADA2016 Tanggal 5 Januari 2017. "Sebagaimana kita ketahui bersama Panwas telah menyerahkan berkas calon BTM-Harus kepada Tim lain yang tak bisa dipertanggungjawabkan dan menjadi konsumsi pihak lain dan tak dibernarkan oleh peraturan yang berlaku," katanya. Keempat, pihaknya juga minta Bawaslu Provisi Papua dan Bawaslu RI untuk menindaktegas oknum Panwas Kota Jayapura yang dengan sengaja menyerahkan berkas calon BTM-Harus kepada pihak lain.

Sementara itu, Ignasius Hasyim menuturkan,terkait KPU Kota Jayapura telah menetapkan satu Paslon, pihaknya akan menggunakan waktu sebanyak 75 persen untuk sosialiasasi dan mengajak pemilih untuk menggunakan hak pilihnya. Pasalnya, pada Pilkada Kota Jayapura tak ada lagi Paslon lain, tapi yang ada hanya ada foto Calon Walikota BTM-harus tanpa Nomor Urut hanya ada foto Paslon BTMHarus. Lalu disampingnya ada gambar kotak kosong.

Dikatakannya, UU memerintahkan pemenangan Paslon yakni minimal 50 Persen +1 . Untuk itu, pihaknya mengantisiasi pemilih yang tak menggunakan hak pilihnya alias Golput pada 15 Pebruari 2017, maka pihaknya akan menggunakan 75 persen waktu untuk mensosialisasikan dan mengajak masyarakat bebondong-bondong ke TPS untuk menggunakan hak pilihnya, demi mensukseskan pesta demokrasi di Kota Jayapura.

Beberapa pekan lalu, isu calon tunggal sempat menjadi buah bibir di masyarakat Kota Jayapura. Ada yang menilai jika calon tunggal maka demokrasi di Pilkada Kota Jayapura sudah mati. Kendati demikian, ada juga yang mendukung adanya calon tunggal. Sementara calon tunggal pun, menjadi polemik di antara masing-masing pendukung bakal calon. Terutama pendukung dari bakal calon Boy Markus Dawir (BMD) dan Nur Alam yang diusung dari partai Demokrat, PPP, dan PKPI. Simpatisan Massa dari BMD beberapa kali sempat melakukan aksi demo damai di halaman kantor KPU Kota Jayapura, menolak adanya calon tunggal.

Kubu BMD meminta agar KPU memverifikasi ulang berkas bakal calon, dan pada akhirnya Panitia Pengawas Pemilu (Panwas) Kota Jayapura mengambil langkah tegas dan memerintahkan KPU Kota Jayapura untuk lakukan kembali verifikasi ulang berkas pendaftaran calon kedua pasangan Calon Wali Kota dan Wakil Walikota Jayapura. Langkah tegas yang dilakukan Panwas Kota Jayapura untuk memverifikasi ulang berkas pendaftaran calon dikarenakan dari kedua pasangan calon, ada beberapa Parpol yang menjadi partai pendukung yang diduga tidak memenuhi syarat. Untuk pasangan BTM-Rustam saru diduga ada lima Parpol, yakni Hanura, Gerindra, Nasdem, PDI-Perjuangan, PAN, Golkar, dan PKPI sebagai Partai pengusung yang terjadi kesalahan administrasi.

Sementara itu, kesalahan Administrasi berkas pendaftaran bakal calon kedua, BTM-Harus dengan BMDAlam, tentang Parpol pengusung Partai PKPI yang menjadi Partai penentu di Pilkada Kota Jayapura, agar terlaksananya Pilkada pada 15 Februari lalu, Komisioner KPU Provinsi Papua, Musa Sombuk, beberapa waktu lalu mengatakan bahwa pihaknya telah membatalkan dukungan dari PKPI pada 11 calon. Karena itu, kalau ada calon yang kurang dari syarat minimal dukungan Partai untuk pencalonan, dinyatakan gugur.

Menurut salah seorang pendukung Paslon bahwa KPU Kota Jayapura, sejak penetapan hingga saat ini sangat menutup diri kepada semua pihak, terutama kepada media yang selalu menanyakan terkait semua tahapan dan terutama tentang calon tunggal di Pilkada Kota Jayapura. 
"Jangan hanya putusan MA itu berlaku di Papua saja. Sebab putusan MA menyebut surat dukungan Partai Politik yang tak ditandatangani Ketua Umum dan Sekretaris Jenderal dianggap cacat hukum, lalu yang kedua dari berkas pendaftaran calon harus melampirkan bekas SK Partai yang dikeluarkan oleh Menkumham."

Hal tersebut ssejalan degam pendapat Budiarjo (2000:118) disimpulkan "bahwa demokrasi tidak hanya merupakan suatu sistem pemerintahan, tetapi juga suatu gaya hidup serta tata masyarakat tertentu, karena itu juga mengandung unsur-unsur moril. Ketua KPU RI, Juri Ardiantoro, mengakui bahwa polemik Pilkada yang terjadi di Kota Jayapura, pada dasarnya merupakan sebuah kesalahan administrasi yang dilakukan oleh lembaga penyelenggara setempat. Menurut sekjen pusat PKIP bahwa "Kami melihat ada upaya dari KPU untuk menggolkan calon tunggal di Pilkada Jayapura. Kami punya bukti kuat, contohnya banyak hal yang direkomendasikan Panwaslu Kota Jayapura, tidak dilaksanakan oleh KPU," tuturnya. Karena itu, Imam bersikeras jika proses penyelenggaraan Pilkada Jayapura tak sesuai aturan perundang-undanga.

Hal senada juga disampaiakn oleh salah satu warga kota jayapura Ariel (30 Tahun) kurang seru karna hanya satu calon tunggal karena berpotensi pada politik yang tidak sehat dan terjadi pembodohan pilitik bagi masayrakat khusus masayrakat kota jayapura

\section{Partisipasi Masayrakat pada Pemilihan Walikota Jayapura Tahun 2017}

Pilkada Kota Jayapura hanya diikuti satu pasangan calon yaitu Benhur Tommy Mano-Rustam Saru dengan jumlah pemilih sebanyak 308.775 pemilih. Jumlah TPS tercatat 629 buah yang tersebar di 39 kampung di lima distrik. Gubernur Papua Lukas Enembe menilai partisipasi pemilih pada pilkada 2017 di Kota Jayapura, Ibu Kota Provinsi Papua rendah akibat tidak maksimalnya kerja Komisi Pemilihan
Umum (KPU) setempat. Dari pantauan lapangan di beberapa Tempat Pemungutan Suara (TPS) diketahui dari total jumlah Data Pemilih Tetap (DPT), tidak sampai 60 persen yang menggunakan hak suaranya. Lukas Enembe yang mencoblos di TPS 23 menilai masyarakat pemilik hak suara banyak yang belum mengetahui mekanisme pilkada yang hanya diikuti oleh satu pasangan calon. "Saya pikir KPU belum maksimal melakukan sosialisasi, mungkin waktu kurang atau di kota ini terlalu banyak masalah. Mungkin juga karena cuma ada satu calon, kalau empat sampai lima calon mungkin banyak yang pilih,"

Ketua KPU Papua Adam Arisoy mengatakan, partisipasi pemilih di Kota Jayapura,Papua untuk memilih wali kota dan wakil wali kota mengalami penurunan 30 hingga 40 persen. Dia mengaku penyebab turunnya partisipasi pemilih di Kota Jayapura belum diketahui secara pasti. Namun, turunnya partisipasi masyarakat untuk memilih itu terlihat dari hasil pantauan di TPS-TPS di sekitar Kota Jayapura, Rabu (15/2). Meski demikian, Adam mengatakan penurunan partisipasi saat pencoblosan tersebut tidak mempengaruhi pelaksanaan pemungutan suara. Hingga sehari setelah pilkada digelar, dia mengaku belum mengetahui hasil sementara karena masih perhitungan di distrik.

Hal yang sama juga diungkapkan Sekretaris Daerah Provinsi Papua TEA Hery Dosinanen, yang menganggap KPU gagal dalam mengolah DPT sehingga banyak wargat yang tidak menerima undangan untuk mencoblos. "Pilkada di kota sedang berjalan, sayangnya banyak masyarakat yang tidak mendapat undangan mencoblos," katanya. Sebagai contoh, dari pantauan lapangan di dua TPS, yaitu di TPS 6 dari 398 DPT, hanya 228 orang yang menggunakan hak pilihnya. Kemudian di TPS 7 hanya 225 suara sah yang masuk dan tiga suara dianggap tidak sah, sementara jumlah DPT 368 jiwa. 
Pilkada Kota Jayapura dilakukan di 629 TPS dan dengan jumlah DPT 308.775, serta hanya terdapat satu pasang calon yang mengikuti Pilkada, yaitu Benhur Tommy Mano dan H Rustan Saruh. Hal Ini yang menjadi perhatian kita, apakah karena kurang sosialisasi, atau masyarakat yang memang memilih tidak datang ke TPS," ungkapnya saat meninjau salah satu TPS di Kelurahan Numbay, Distrik Jayapura Selatan, Rabu (15/2) siang.

Lebih lanjut Menurut salah satu warga kota jayapura (John 30 Tahun) saat diwawancara bahwa pemilihan wali kota jayapura denga satu pasangan calon..tidak demokrasi karena tidak terdapat nilai demokrasi . dan KPUD pusat maupun propinsi tidak melihat kebutuhan daerah . hal ini sangat merugika pasangan calon yang lain. Dan juga masyarakat tidak dapat memberikan pihan sesuai dengan hati nurani

\section{KESIMPULAN DAN SARAN KESIMPULAN}

KPU Kota Jayapura dan Pemkot Jayapura sebagai pembina politik di Kota Jayapura terkait Pilkada Kota Jayapura periode 2017-2022, untuk pertama kalinya menyelenggarakan Pilkada dengan Pasangan Calon (Paslon) Tunggal, dan demi kelancaran pesta demokrasi ini didesak segera melakukan sosialisasi mekanisme Paslon .

Komisi Pemilihan Umum (KPU) Kota Jayapura memutuskan hanya satu pasangan sah yang bisa mengikuti Pilkada Jayapura pada 15 Februari 2017, yakni pasangan calon wali kota dan calon wakil wali kota Benhur Tomi Mano-Rustam Saru (BTM-Harus). Pasangan BTM-Harus dinilai KPU memenuhi syarat untuk mengikuti PILKADA KOTA JAYAPURA. Pilkada Kota Jayapura hanya diikuti satu pasangan calon yaitu Benhur Tommy Mano-Rustam Saru dengan jumlah pemilih sebanyak 308.775 pemilih. Jumlah TPS tercatat 629 buah yang tersebar di 39 kampung di lima distrik. Dari pantauan lapangan di beberapa Tempat Pemungutan Suara (TPS) diketahui dari total jumlah Data Pemilih Tetap (DPT), tidak sampai 60 persen yang menggunakan hak suaranya Sebagai contoh, dari pantauan lapangan di dua TPS, yaitu di TPS 6 dari 398 DPT, hanya 228 orang yang menggunakan hak pilihnya. Kemudian di TPS 7 hanya 225 suara sah yang masuk dan tiga suara dianggap tidak sah, sementara jumlah DPT 368 jiwa. Pilkada Kota Jayapura dilakukan di 629 TPS dan dengan jumlah DPT 308.775. KPU belum maksimal dalam melaksanakan sosialisasi Paslon Tnggal sehingga mengakibatkan pertipasi pemilih rendah

\section{SARAN}

1. Kepada KPU adalah baro meter sukses dan gagalnya pilkada, maka itu harus bebas dari kepentingan balon dan politik uang serta pentingnya prinsip Netralitas dan integritas oleh KPU Kota Jayapura, sebab konflik pilkada sering muncul karena ketidak netralan Komisioner KPU

2. KPU dan Panwas harus sejalan dan saling koordinasi agar pesta demokrasi dapat berjalan dengan baik dan lancar.

3. Masyarkat harus tetap tenang dan menerima keputusan KPU dan tidak boleh mudah terpancing dengan isu-isu yang tidak bertanggung jawab

\section{DAFTAR PUSTAKA}

Abdulkarim, Aim. 2010. Pendidikan Kewarganegaraan: Membangun Warga Negara yang Demokratis". Jakarta: PT Grafindo Media Pratama.

A. Ubaedillah dan Abdul Rozak, 2008. Pendidikan Kewarganegaraan Edisi Ketiga (Demokrasi, Hak Asasi Manusia dan Masyarakat Madani). Jakarta: Prenada Media Group. 
Aa Nurdiaman, Pendidikan Kewarganegaraan: Kecakapan Berbangsa dan Bernegara. Jakarta: PT Grafindo Media Pratama

Mochlisin. 2007. Pendidikan Kewarganegaraan untuk SMP. Jakarta: Interplus.

Gunawan, Markus. 2008. Buku pintar calon anggota dan anggota legislatif, DPR, DPRD dan DPD. Tangerang: Visimedia.

St. Benn and R.s Peters. Principels of political thought (New york : Collier Books, 1964). h. 393.

Sugiyono, (2011), Metode Penelitian Kuantitatif Kualitatif dan $R \& D$, Alfabeta Bandung.

Sorensen, Georg. (2003). Demokrasi dan Demokratisasi (Proses dan Prospek dalam Sebuah Dunia yang Sedang Berubah). Yogyakarta : Pustaka Pelajar.

Soekanto, Soerjono. (1990). Sosiologi Suatu Pengantar. Jakarta : PT Raja Grafindo Persada. Publik (KOMPIP).

Sulastomo, (2014), Cita-Cita Negara Pancasila. Penerbit PT Kompas Media Nusantara Jln Palmerah Selatan 26-28, Jakarta10270

Pradhanawati, Ari (Peny). (2005). Pilkada Langsung Tradisi Baru Demokrasi Lokal. Jakarta: Konsorsium Monitoring dan Pemberdaya Institusi.

Prihatmoko, Joko J. (2005), Pemilihan Kepala Daerah Langsung: Filosofi, Sistem dan Problema Penerapan di Indonesia. Yogyakarta: Pustaka Pelajar.

Putra, Febri Purnama. (2009). Meretas Perdamaian Dalam Konflik Pilkada Langsung. Yogyakarta: Gava Media.

Rubin, Jeffrey Z. (2004). Teori Konflik Sosial. Yogyakarta: Pustaka Pelajar.

Rais, Amien (Pengantar). (1986). Demokrasi dan Proses Politik. Jakarta: LP3ES Pendidikan Nasional.

Rizkiyansyah, Ferry Kurnia. (2007). Mengawali Pemilu Menatap Demokrasi (Catatan Penyelenggaraan Pemilu 2004). Bandung: IDEA Publishing. 